\title{
CONSERVATION AND MANAGEMENT PRACTICES OF TRADITIONAL CROP GENETIC DIVERSITY BY THE FARMERS: A CASE FROM KAILASH SACRED LANDSCAPE, NEPAL
}

Kamal Aryal ${ }^{1}$, Sushmita Poudel ${ }^{2}$, Ram Prasad Chaudhary ${ }^{3}$, Nakul Chettri ${ }^{4}$, Wu Ning ${ }^{5}$, Yi Shaoliang ${ }^{6}$ and Rajan Kotru ${ }^{7}$

\begin{abstract}
Crop genetic diversity has been an important source of subsistence livelihoods and nutrition in the remote Himalayan region for local communities. This study documents the crop diversity, their current status and farmer's knowledge and practices. Study was based on analysis of one local crop diversity fair, 18 key informant surveys, nine focus group discussions and 195 individual household surveys with set questionnaires. The community structure in the study area has female dominance (52\%) with average family size of 7.1. The study documents 78 species of various crops which were used as food, vegetables, fruits, medicine, and spices. Highest varietal diversity was recorded in Maize (15), Paddy (12), wheat (11), and beans (10). However, a number of crop varieties are being lost and threatened over the time. Both anthropogenic and natural drivers of changes were reported as the major reason of such loss. Despite loss of crop varieties farmers have been maintaining a wide range of crop and varietal diversity in situ on farm by their own initiatives and experiences. Our study showed that self-saved seed contributed as the major source of planting material through which they are maintaining the crop diversity. However, a detailed study on the seed supply system is needed to support easy access to the farmers. More awareness raising program as well as empowerment of farming communities is essential for the continuation of conservation and management practices.

Key words: Crop and varietal diversity, diversity fair, loss and threatened species, self-saved seed, Kailash Sacred Landscape
\end{abstract}

\section{INTRODUCTION}

Agro-biodiversity has been recognized as an important factor in maintaining or enhancing agricultural sustainability and playing a significant role for the food security and livelihoods of a large number of local communities around the globe (Uprety 2000; Baldinelli 2014). Agriculture combined with agro-pastoralist communities is the basis of the livelihoods for over 80 percent of the rural population in the Hindu Kush Himalayan (HKH) region and has been recognized as a hotspot for

$1 \quad$ NRM analyst and PhD Scholar, International Centre for Integrated Mountain Development (ICIMOD), and Research Centre for Applied Science and Technology (RECAST), Tribhuvan University (TU), Kathmandu, Nepal GPO Box 3226,Tel + 977-1-5003222, Fax +977-1-5003299 kamal.aryal@icimod.org

2 Research Assistant and Field Coordinator, sus. poudel22@gmail.com

3 Professor Emeritus (Chief Technical Advisor), RECAST, TU, Kathmandu, Nepal. PO Box 1030,Tel + 977-1-4330348, Fax +977-1-4331303 ram@cdbtu.wlink.com.np

4 Senior Biodiversity Specialist, ICIMOD, GPO Box 3226, Tel + 977-1-5003222, Fax +977-1-5003299 nakul.chettri@icimod.org

5 Theme Leader, Ecosystem Management, ICIMOD, GPO Box 3226,Tel + 977-1-5003222, Fax +977-1-5003299 wu.ning@icimod.org

6 Senior NRM Specialist, ICIMOD, GPO Box 3226,Tel + 977-1-5003222, Fax +977-1-5003299 yi.shaoliang@icimod.org

7 Regional Programme Manager, ICIMOD, GPO Box 3226,Tel + 977-1-5003222, Fax +977-1-5003299 rajan.kotru@icimod.org 
crop diversity (Agnihotri and Palni, 2007). The traditional local cultivars, also known as landraces or farmer's varieties contribute significantly to sustainable food production, human nutrition and household income generation for the resource poor farmers in marginal agricultural areas and to overall climate resilience building (Baldineli, 2014; Katwal et al. 2015). Genetic diversity of traditional varieties of crops is the most economically valuable element of global agro-biodiversity and is of paramount importance for future world crop production (Rana et al. 2007; Galluzi et al. 2010). High genetic diversity of the local crops is a defense against pests, diseases and environmental changes and makes landraces more suitable than commercial varieties (Negri 2005). The HKH region has been identified as a repository for traditional knowledge widely used in natural resource use and conservation (Bist et al. 2007). However, due to socio-demographic changes such as out-migration of the younger generations to urban areas is resulting in loss of such knowledge. It is essential that such traditional knowledge and practices be conserved (Chaudhary et al. 2007; Rana et al. 2007; Chaudhary and Aryal 2009; Zomer and Oli 2011).

In the other hand, changes in agricultural land use system and climatic and non-climatic factors have caused a significant decrease in agricultural diversity (Aase et al. 2009; Chaudhary et al. 2011; Baldinelli, 2014). Furthermore, in recent years local varieties are being replaced by exotic varieties promoted by public schemes for higher production and specific robustness criteria for example pest resistant and drought resistant (Oli, 2003; Verma et.al 2010; Hyder et al. 2014) limit the option for farmers in having a balanced nutrition. On the otherhand, knowledge about climatic and nonclimatic changes and their impact on food security and crop genetic resources management in the region have not been well documented (Aase et al. 2009; Singh et al. 2010; Chaudhary et al. 2011; Zoomer and Oli 2011; ).

Indigenous and traditional agricultural communities act as the sole managers and custodians of local crop varieties and utilize their knowledge to maintain and manage diverse agricultural production system (Upadhyay \& Subedi, 2003; Bisht et al. 2007). They have been accumulating knowledge about the agricultural practices through implementing wide range of indigenous and traditional practices based on generations of experience, informal experiments and intimate understanding of their environments (Abioye et al. 2011; Berkes et al. 2000; Usher 2000). These traditional knowledge and practices include numerous adaptations strategies at local context and also transmission of knowledge and practices to younger generations (Berkes et al 2000; Salick and Byg, 2007). However, the valuable knowledge gathered and practiced by farmers over generations is often neglected by researchers, although the information is quite essential for location specific recommendations and for developing sustainable farming systems (Abioye et al. 2011). Furthermore, lack of proper documentation of the traditional knowledge and practices, a number of crop varieties are eroding from the areas without proper knowledge of farmers about varieties and their cultivation (Sunwar et al. 2006; Regmi et al. 2009; Baral et al. 2012).

Having these contexts and background, this paper is trying to assess the richness and status of the local crop genetic resources and associated knowledge and practices of the local communities in Khar Village Development Committee (VDC) of Kailash Sacred Landscape, Nepal. We tried to document and analyze farmers' local knowledge and practices on managing crop diversity, not only in terms of 'what', 'who' and 'how', but also 'why', so that the blending of scientific and local knowledge is achieved for strengthening farmers' capacity and interest to continue growing 
traditional crop varieties for the long-term security of livelihoods of the local people as well as maintain high diversity on-farm so that climate resilience is inbuilt.

\section{OBJECTIVE}

This paper aims to document the status of crop diversity and traditional management practices adopted by the local people to manage the crop diversity on farm. The specific objectives were to:

- know the current status of local crop diversity and their changes over time;

- understand and document various anthropogenic and climatic drivers of change affecting the choice and management of crop genetic resources; and

- document local knowledge/practices and adoption strategies used by the local people for management of crop diversity on farm.

\section{MATERIALS AND METHODS}

\section{STUDY AREA}

The present investigation was particularly carried out in Khar VDC of Api Nampa Conservation Area

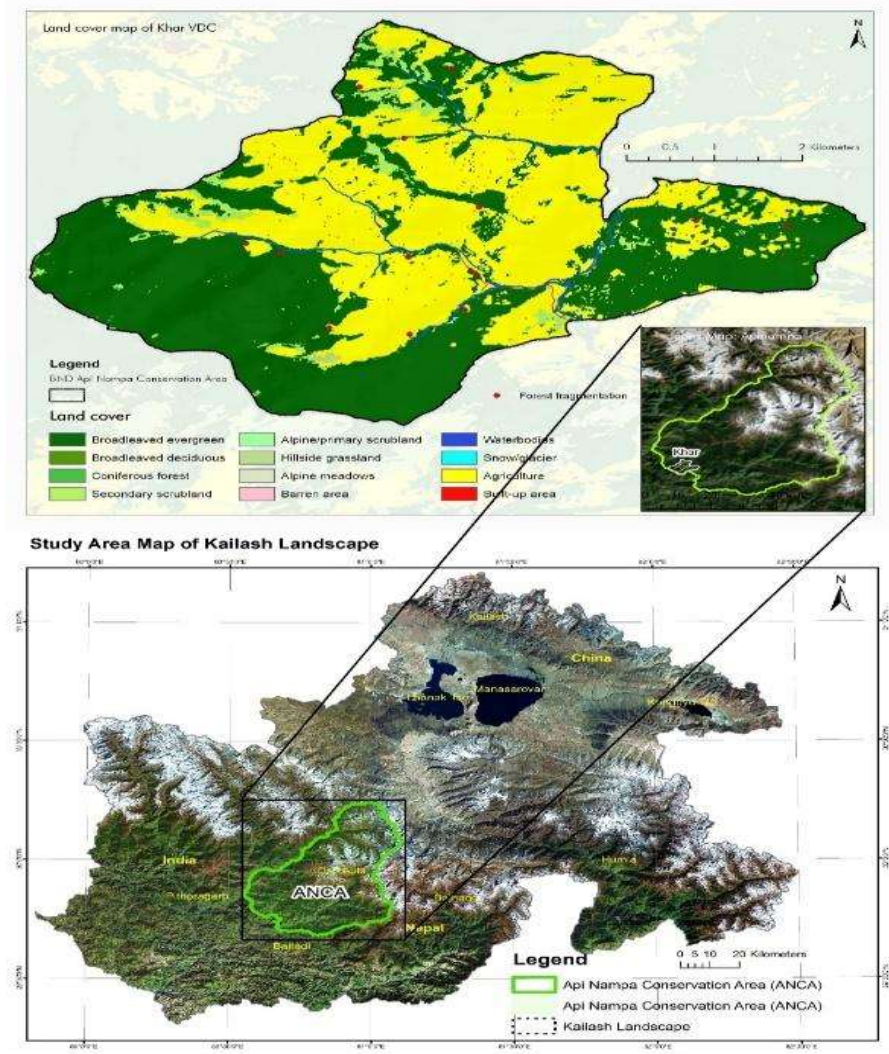

Figure 1: Study site (Land cover map of Khar VDC)
(ANCA) (Figure 1). The elevation of the VDC ranges from 1,324 to 3,242 masl with subtropical climate at lower part and temperate in the upper reaches. The area is located at about 3 hour walk from Khalanga Bazaar, the district headquarter of Darchula district and also connected by rural road $(14 \mathrm{~km})$ with Khalanga Bazaar. The access of the vehicle is only possible during the winter and spring seasons (not in monsoon). With an area of $25.95 \mathrm{~km}^{2}$, Khar VDC has 698 households with population of 4,272 (CBS 2012). Nearly half of the VDC area $(51.1 \%)$ is covered by forest, other land use types are agriculture (44.3\%), shrub land $(4.1 \%)$, water bodies $(0.31 \%)$, grassland $(0.11 \%)$ and settlement area $(0.07 \%)$ (ICIMOD, 2013). 


\section{DATA COLLECTION}

The research methodology involved both primary data collection and through literature review. For the primary data collection, sample size for household survey was determined using the following formula:

Number of households to be audited $=\frac{Z^{2} 1-{ }^{*} N{ }^{*} P(1-P)}{\left(e^{2 *} N\right)+\left(Z^{2} 1-X * P(1-P)\right.}$

Where,

$N$ is the total number of households in the population $(\mathrm{N}=698)$

$Z$ is the level of confidence (assumed value for $90 \%$ level of confidence is 1.65 );

$P$ is the estimate of the indicator to be measured (assumed value $50 \%$ in the absence of any prior information)

$e$ is the margin of error to be attained (assumed level of precision is set at 5\%)

Under the above assumptions, a total of 195 households were selected for the detailed household survey. To have proper representation from each ward, the estimated sample size was proportionally distributed as per the number of households in nine wards of the VDC. Planned structured questionnaire for household survey was prepared and carried out in 195 households of Khar VDC. In addition, nine focus group discussions (one in each ward) were carried out and at least 18 key informants were interviewed. During the key informant's interviews, older people (more than 50 years of age) were consulted to gather traditional knowledge and practices about the local crop diversity. Farmer's recall method followed by Focus Group Discussions (FGD) was organized to see the changes of local crop diversity in last 10 years from their area. They were asked to identify the lost and threatened species along with the associated reasons. Besides, agricultural crop diversity fair was organized in Dallekh of Khar VDC in February 2016 in collaboration with District Agriculture Development Office (DADO) and Api-Nampa Conservation Area. During the fair local genetic materials were displayed, their indigenous/local knowledge were shared and documented and traditional food were also prepared from the local crops.

For data analysis, a questionnaire format was prepared in CS Pro 6.2 and then the survey data was entered into the program. Descriptive statistics like mean and frequency distribution were used to describe the household characteristics using Statistical Package for Social Sciences (SPSS, 2011) 16.0 Software.

\section{RESULT AND DISCUSSION}

\section{SOCIO-ECONOMIC PROFILE}

The farmers in the study site live under different socio-economic conditions in terms of education, family size, age group, occupation, and income source and food sufficiency level (see Table 1). The number of interviewed persons was 195 (94 male and 101 female). 
The average household size of the study site is 7.1 which is higher than the district average of 5.41 and further the figure is higher than the national average i.e. 4.88 (CBS 2012). In general, the literacy rate is very low, only 39.3 percent can read and write their name and the rest 60.7 percent of the respondents were illiterate. This can be compared to the national literacy rate of $65.9 \%$ (CBS 2012).

Overall, agriculture was ranked as the most important occupation by majority of the respondents (84\%). However, their self-grown food is only sufficient for 5 percent of the households. About 82 percent of the household could only live for 7-10 months on products from their own agricultural production and 13 percent of the household could live for less than 6 months from their own agricultural production. During the food deficit period households depend on multiple coping strategies such as wage labor, salaried employed, remittances, share cropping and collection of wild foods.

Table 1: Socio-economic features of the respondents.

\begin{tabular}{|l|c|}
\hline Categories & No. of respondents (N=195) \\
\hline Sex & $94(48 \%)$ \\
\hline Male & $101(52 \%)$ \\
\hline Female & $37(19 \%)$ \\
\hline Age group & $50(26 \%)$ \\
\hline $15-25$ years & $74(38 \%)$ \\
\hline $26-40$ years & $34(17 \%)$ \\
\hline $41-55$ years & 7.1 \\
\hline$>56$ years & \\
\hline Average HH size & $118(60.7 \%)$ \\
\hline Education & $57(29.1 \%)$ \\
\hline Illiterate & $20(10.2 \%)$ \\
\hline Class 1-11 & NRs 142,688 \\
\hline Class 12-15 & \\
\hline Average income earned per HH & $25(12.8 \%)$ \\
\hline Food sufficiency level (months from self-grown food) & $160(82.1 \%)$ \\
\hline Up to 6 months & $10(5.1 \%)$ \\
\hline 7 -10 months &
\end{tabular}

Note: Proportions in different categories are presented within brackets.

\section{CROP DIVERSITY IN THE STUDY SITE}

Altogether 78 different species of various crops cultivated in the study site were documented through crop diversity fair organized in February 2016 in the study site. Traditionally, people grow wide range of crops for their livelihoods sustenance. The eight major crops grown by surveyed households are presented in Figure 2. Within the crops the highest diversity was recorded in Maize 
having 15 different varieties followed by paddy (12) and wheat (11) as indicated in Table 2 . The name of the varieties mentioned in the table are given by the farmers based on their own descriptor during diversity fair where all these varieties were displayed. Some of the varieties displayed during the fair looked similar hence further detail analysis is needed to verify by establishing experimental plots using standard descriptors. Despite high varietal diversity, majority of the households grow only a few varieties on the farm.

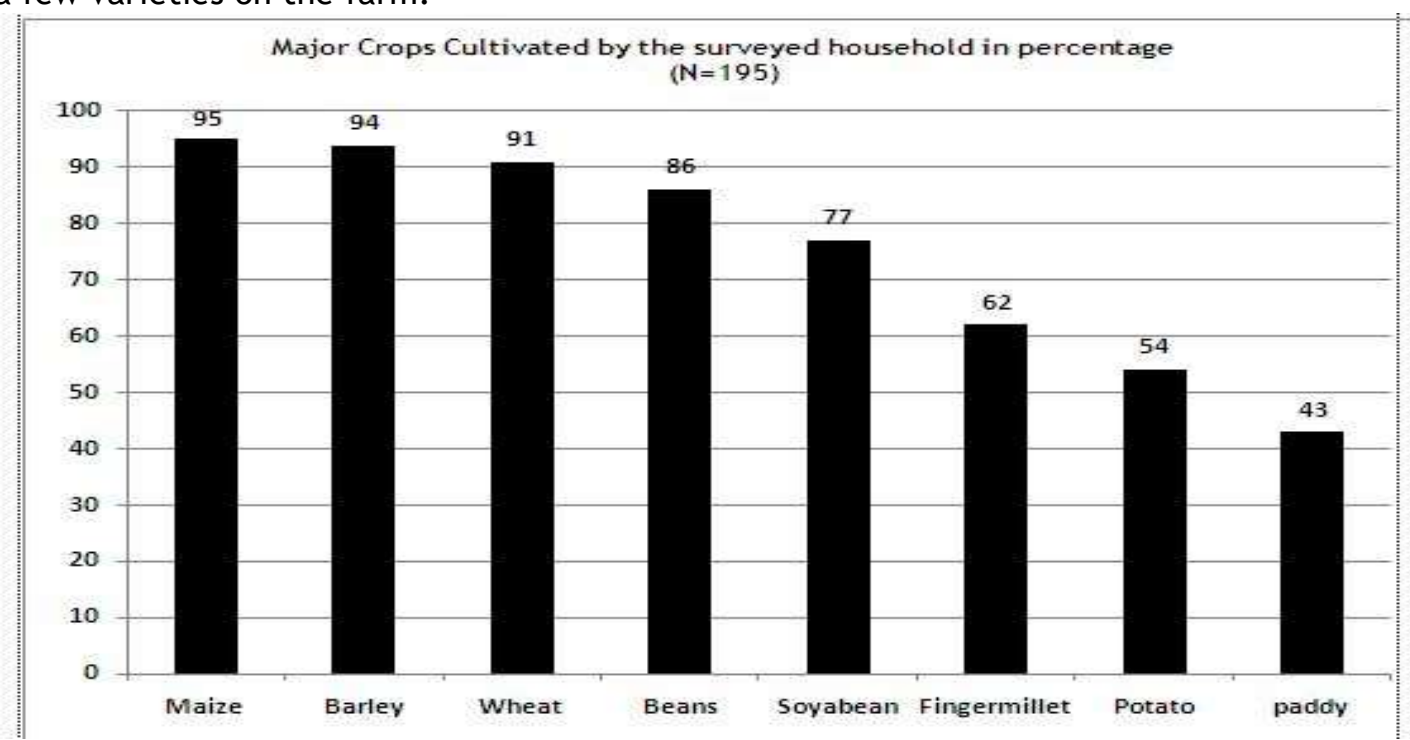

Figure 2: Major crops cultivated by majority of the household in Khar

\section{STATUS OF CROPS AND CHANGES OVER TIME}

Many of the participants in FGD recalled and reported that they used to cultivate large number of local crops species and varieties in their agriculture field in the past and are now not cultivated in the area. The reported lost and threatened species were mostly local crops and varieties of wild species. With this decline, crop varieties of various species are disappearing. A number of varieties of major crops grown in the area are disappearing (see Table 2). The cultivation of traditional crops such as finger millet, proso millet, fox tail millet, amaranths, rice bean and buckwheat has decreased in the last 10 years and it has become extremely difficult to even find the seeds of these crops. One of the older varieties of wheat (Malaya variety) is reported to be completely lost from the study area. Many old varieties of barley such as jhuse jau, thaang jau and kalo jau and maize such as baktado, ragase and rato bilaas are very difficult to find. The older varieties of beans such as black and white beans are also in the state of rapid decline. Two important reasons mentioned for such decline were low production potential and long crop duration which do not allow increasing cropping intensity. Similar reasons were mentioned in the study area carried out by Rana et al. (2007) and Rijal (2007). If this process continues, many such older varieties of crops will be lost forever without even being documented. This will not only reduces the local crop diversity but also increases farmer's vulnerability to climate related changes resulting on loss of traditional farming system (Bisht et al. 2007; Singh et al. 2010). 
Table 2: Agricultural crop diversity of major crops grown locally (source: Diversity fair-2016)

\begin{tabular}{|c|c|c|c|c|}
\hline Crop & $\begin{array}{l}\text { Local } \\
\text { name }\end{array}$ & $\begin{array}{l}\text { Botanical } \\
\text { name }\end{array}$ & Varieties & Remarks \\
\hline Paddy & $\begin{array}{l}\text { Dhan } \\
(12)\end{array}$ & $\begin{array}{c}\text { Oryza } \\
\text { sativa L. }\end{array}$ & $\begin{array}{c}\text { Khasare, Sali, Chamade,Takmaro, } \\
\text { Roti dhaan, Choti dhaan, Jaili } \\
\text { dhaan,Jumli dhaan, Kirmuli } \\
\text { dhaan,Jau dhaan, Mangali } \\
\text { dhaan, Rato dhaan }\end{array}$ & $\begin{array}{c}\text { Jau dhaan and Sali dhan are } \\
\text { almost eroded from Khar VDC only } \\
\text { a couple of farmers maintain these } \\
\text { varieties in small land area }\end{array}$ \\
\hline Wheat & $\begin{array}{l}\text { Gau } \\
(11)\end{array}$ & $\begin{array}{l}\text { Triticum } \\
\text { aestivum } \\
\text { L. }\end{array}$ & $\begin{array}{c}\text { Dautkhane, Bhote, Rato, Thulo, } \\
\text { Jhuse, Geru,Moto, Haasa, Lide, } \\
\text { Jumli Bhoto, Nangri Bhoto, }\end{array}$ & $\begin{array}{c}\text { Jhuse, Haasa, Geru and Dautkhane } \\
\text { varieties have been eroding from } \\
\text { the area }\end{array}$ \\
\hline Maize & $\begin{array}{c}\text { Ghoga } \\
(15)\end{array}$ & $\begin{array}{c}\text { Zea mays } \\
\mathrm{L} .\end{array}$ & $\begin{array}{c}\text { Bhabari, Rato, Murali,Temase, } \\
\text { Pahelo, Seto,Bhate, Ragese, } \\
\text { Airkoti,Male, Baktado, Ghar, } \\
\text { Baure, Marudi, Bikasi }\end{array}$ & $\begin{array}{l}\text { Baktado variey is grown by only } \\
\text { one farmer and Rato, ragase are } \\
\text { also in the verge of disappearing } \\
\text { from the area due to its low yield }\end{array}$ \\
\hline $\begin{array}{l}\text { Finger } \\
\text { millet }\end{array}$ & $\begin{array}{l}\text { Kodo } \\
(7)\end{array}$ & $\begin{array}{l}\text { Eleusine } \\
\text { coracana } \\
\text { Gaertn. }\end{array}$ & $\begin{array}{c}\text { Nang kate, Kalo, Rato,Temase, } \\
\text { Tiuli, Mutke,Kodekauli }\end{array}$ & $\begin{array}{c}\text { All the varieties are disappearing } \\
\text { due to its low yield and shifting } \\
\text { towards new maize varieties } \\
\text { introduced by DADO }\end{array}$ \\
\hline Barley & Jau (5) & $\begin{array}{l}\text { Hordeum } \\
\text { vulgare L. }\end{array}$ & $\begin{array}{c}\text { Jhuse, Mankare, Kalo, Seto, } \\
\text { Thang Jau }\end{array}$ & $\begin{array}{c}\text { Jhuse, Kalo, and thang are almost } \\
\text { disappeared from the area }\end{array}$ \\
\hline Beans & $\begin{array}{l}\text { Sotta } \\
(10)\end{array}$ & $\begin{array}{l}\text { Phaseolus } \\
\text { vulgaris L. }\end{array}$ & $\begin{array}{l}\text { Seto local, Kalo local, Rato } \\
\text { Kirmire, Kaleji Kirmire, Asali } \\
\text { rajma, Marma, Temase, } \\
\text { Bote, Kalo, Batule, Ankhe Simi }\end{array}$ & $\begin{array}{l}\text { Seto and Kalo are two of the } \\
\text { oldest varieties grown only few } \\
\text { households (less than } 10 \\
\text { households in Khar VDC) }\end{array}$ \\
\hline
\end{tabular}

\section{FARMERS PERCEPTION ON LOSS OF CROP GENETIC RESOURCE}

The multiple response on perceptions of respondents for both anthropogenic and natural drivers of changes on the loss and threatened varieties of the crops were recorded in the study area. The first important reason for loss of local crop diversity has been accelerated by the introduction of improved crops and varieties which is reported by 150 respondents out of 195 (Figure 3). About 94 percent of the respondent reported that easy availability of improved and hybrid varieties of crops is considered the leading cause of local crop diversity loss. It is followed by out and seasonal migration of the skilled human resources (110 respondents). Now, the trend changed as people migrate seasonally to India or abroad to work as wage laborers creating shortage of labor to work in agricultural fields which directly affects the crop diversity management. Other anthropogenic causes mentioned by the people are easy accessibility of road and market. Before roads were built people's livelihoods completely depended on self-grown food and mostly the traditional varieties of crops they grew in their fields. As the resources are easily available due to access to road and market people prefer buying rice from the market rather than depending on their production (Figure 3). 


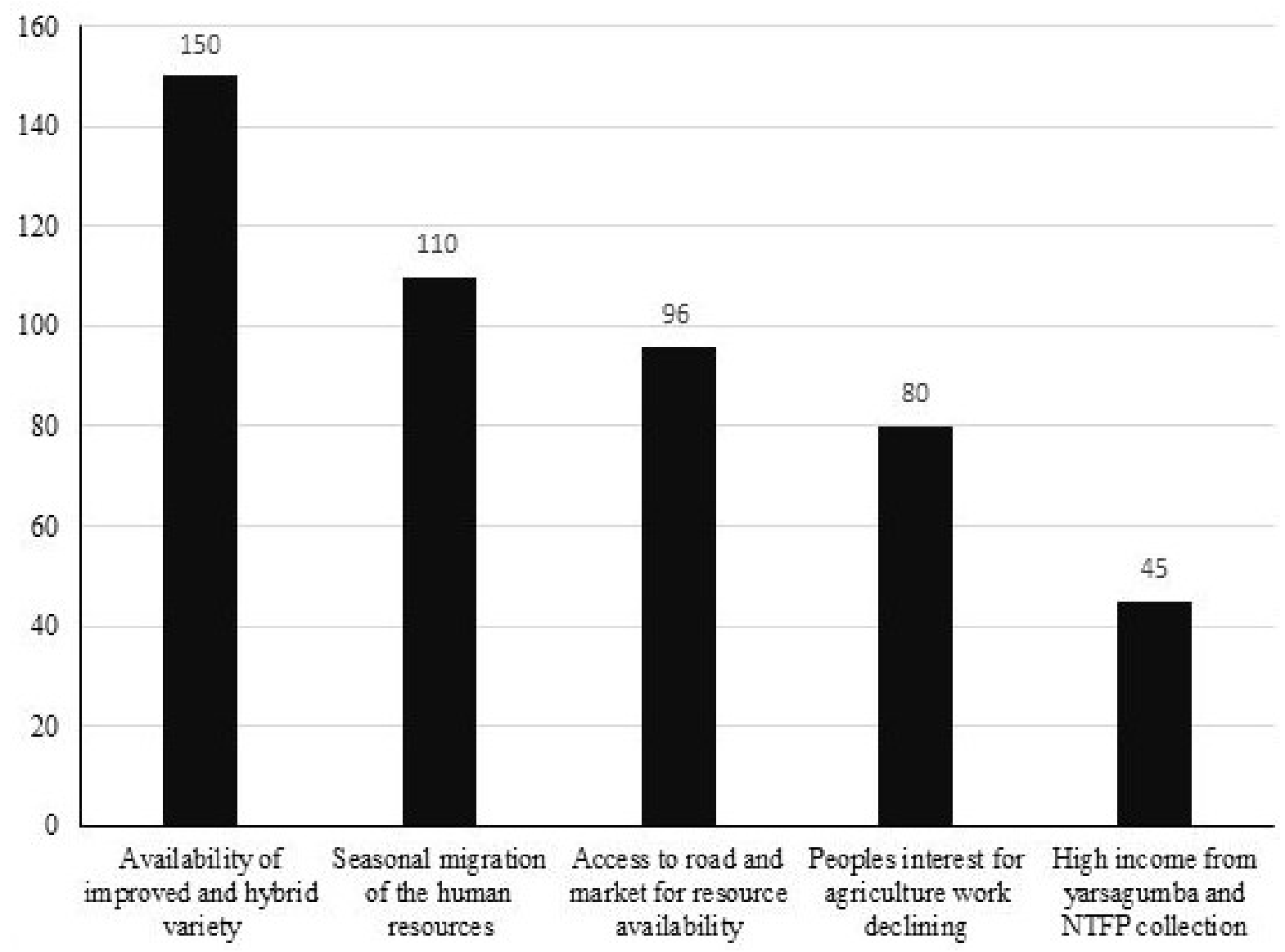

Figure 3: People's perception on anthropogenic reasons causing crop diversity management

We also conducted key informants interview with several elderly people and discuss the natural drivers of changes. A multiple and wide range of responses were recorded based on their own experiences and stories. Overwhelming (90\%) of the respondent experiences that the climate is changing. Their experiences broadly range from erratic weather pattern, ecological variability, biological changes and their negative effects on local people's life. However, they are not quite sure whether these kinds of changes are because of climate only or linked to other associated reasons. We also tested several theories by asking the local people about their perceptions on changes that they are experiencing in their lifetime. To do this, at first we organized a FGD and asked them to share their various climate change related practical experiences. We listed them and prepared a major areas of changes that the local people who are experiencing in their locality and later included them in the household survey questionnaire where mixed response were recorded (see Table 3). We only presented responses on climate change related experiences which was mentioned by more than 50 percent respondents. In column 3, where respondents are not experienced the changes and in the last column the respondent didn't have any idea about such 
changes. Studies by Chaudhary and Aryal (2009) and Uprety and Ghale (2002) also supported our current study findings.

Table 3: People's experiences on natural drivers of change related happenings

\begin{tabular}{llcc}
\hline \multicolumn{1}{c}{ Local people perception on various climate change related issues } & Yes & No & No Idea \\
\hline Experiencing long summer (more hotter days) & 105 & 29 & 61 \\
Less snowfall & 130 & 20 & 45 \\
Less rainfall during winter & 110 & 40 & 45 \\
Drying up the water sources & 150 & 15 & 30 \\
Longer duration of drought & 160 & 10 & 25 \\
Early flowering of rhododendron & 120 & 25 & 50 \\
Never seen weeds present in agriculture field & 160 & 10 & 25 \\
Insect pest attack on local varieties & 110 & 30 & 55 \\
New species adopted well & 122 & 50 & 23 \\
\hline
\end{tabular}

\section{LOCAL MANAGEMENT PRACTICES AND ADAPTATION STRATEGIES}

\section{Seed management practice}

The present study revealed that local seed sources are important for maintaining and managing crop diversity in their farm. A multiple responses on managing the seeds for next season have been recorded during the survey. Self-saved seed (reported by $98.5 \% \mathrm{HHs}$ ) are the first source of planting materials and has the highest contribution to all of the major farm components; cereals, pulses, vegetables, fruits, and spices and sharing between and among the neighbors contributed the second most important. Interestingly, their relatives play significant role in management of crop diversity by contributing third place as reported by 55 percent of the respondents (see Figure 4). Self-saved seeds are the primary source of seed management in other parts of Nepal where community people stored seeds for the next cultivation (Rijal et al. 1998; Poudel et al. 2015). But such a study is lacking focusing on local crop species particularly in far-western hilly districts and Kailash Sacred Landscape area. The proper management of traditional varieties depends on the continued functioning of informal seed exchange networks as it accounts for large proportion of seed exchange in various parts particularly in rural areas (Hodgkin et al. 2006). Therefore, local seed management through informal seed system needs to be strengthened to manage crop diversity in farmer's field.

In the other hand, many local crop varieties are lost and many more are threatened in the farmer's field. The present study reported that a number of crops like Marshe (locally called chuwa) (Amaranthus L.), finger millet (Eleusine coracana L.), proso millet (Panicum miliaceum L.), and foxtail millet (Setaria italica (L.) Beauvois) are already in threatened condition in the study area. Therefore, such threatened crop species could be placed for ex-situ conservation where the formal institution could further improve the crop quality and resend them back to the community.

Furthermore, product diversification on these crops can enhance the conservation of these crop varieties on long run. Therefore, policy makers, researchers and other relevant organizations should initiate measures towards ex-situ conservation for threatened local crop varieties. 


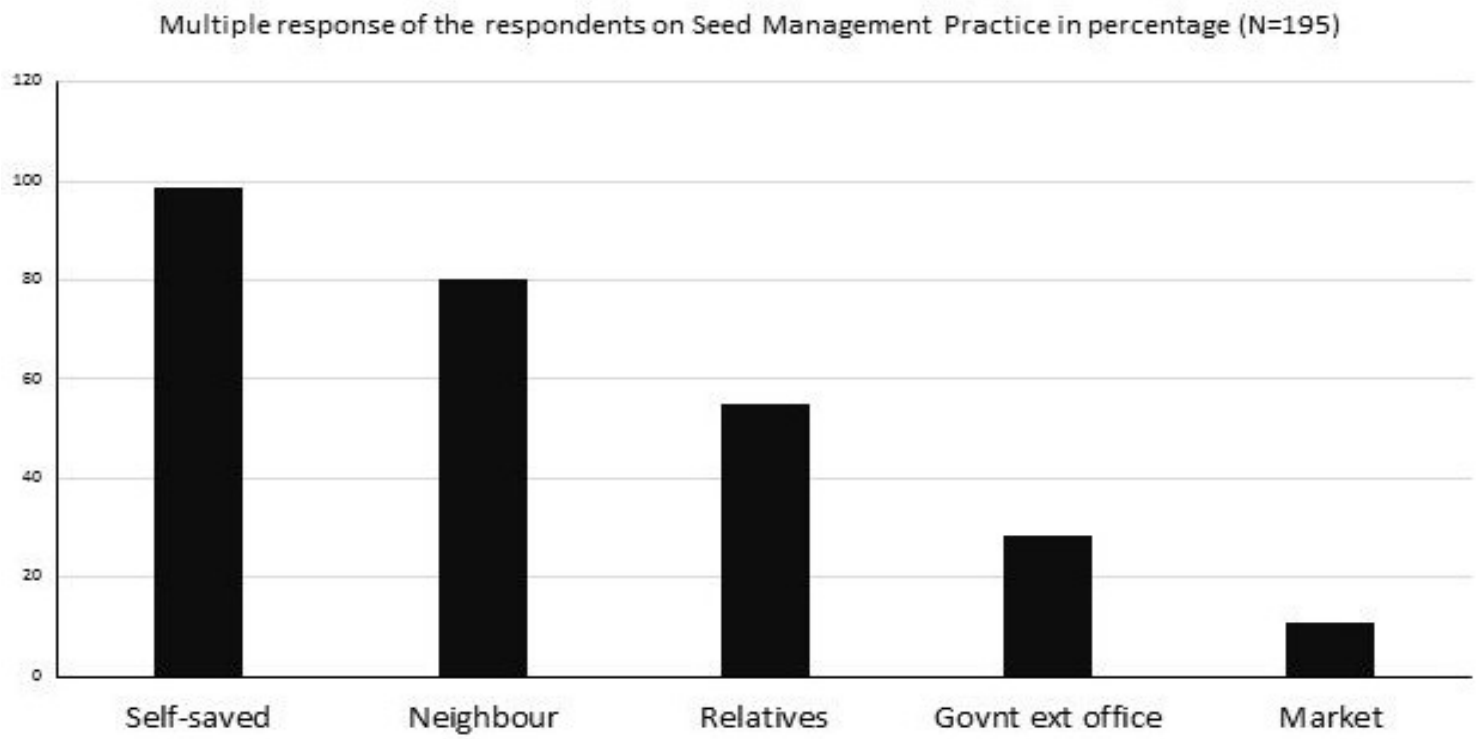

Figure 4: People's response on seed management practice

\section{Women's role on seed selection and management}

Once we knew majority of the households keep their own grown seed for the next cultivation, we asked the respondents who manages the seeds most in their household. About 82 percent of the respondents mentioned that the management of local crop diversity is one of the key responsibilities of women because they are good in seed selection, seed storage and seed supply/exchange. Since women are the ones who do the actual seed selection, they select according to their preference and household needs. In this regard we asked women to exchange their views and information regarding seed management practice. They have the information on how seed is selected and stored, and what varieties and seed qualities others have in the village. In this way, they serve as the manager because they know who has what seeds and their quality and are the member of informal seed network at village. Farmer's seed networks play an essential role to help ensure access to varieties at risk and enable and incentivize on-farm conservation of crops diversity. They create the linkage between farmers and provide channels for mutual assistance (Sperling and Mcguire 2010). Research shows that the communities with weak social networks tend to be more vulnerable to adverse conditions because of constrained access to locally adapted seeds compared to those communities with strong social seed networks (Poudel et al. 2005). So, this seed networks needs to be studied well and their importance in conservation of local crop diversity should be valued. Informal/social seed systems almost entirely provide the supply of seeds of traditional varieties (Poudel et al. 2015).

\section{Farmer's initiatives and local adaptation strategies to manage crop diversity}

Our current study indicates that farmers have initiated various local level adaptation practices to minimize the impacts of both climatic and non-climatic changes. The findings suggest that about 87 percent of the surveyed households reported that they practice intercropping i.e. planting two or more crops together such as growing maize and beans together. Interestingly, about 75 percent of 
the respondents mentioned that they carefully do the right crop and seed selection to avoid adverse conditions (Table 4). For instance, local people in Khar cultivate Dautkhane (local wheat variety having drought resistant) when they thought this year dry period likely to be longer. Other on farm adaptation practices (see Table 4) are changes in planting time and location, soil management, diversifying livelihoods options like depends more on off-farm work. Adopting off-farm works such as mat making, wage labor helped to earn additional income for the family to cope with such changes.

Similar study carried out by Ajani et al. (2013); Unruh (2004); Bellon (2008) also shows that diversification of crop varieties is one of the potential adaptation options to reduce vulnerability to climatic and non-climatic variability and changes. It is also common to other parts of Nepal where farmers increase the crop diversity to reduce such adverse effects (Poudel et al. 2015; Rana et al. 2007). Policy incentives to cultivate the new modern variety sometimes forced farmers to grow only a single variety which is also contributing in reducing crop diversity on farmer's field (Di Falco and Perrings 2005). In these contexts, it is better to encourage farmers to use more local crop varieties to grow diverse crops in their farm rather than providing incentives and reward to those farmers who grow only one or two crops in commercial scale.

Looking at the various strategies and practices that the farmers are practicing indicates that farmers in the study sites are very cautious about the changes and are constantly looking for the ways to adapt such changes. However, the study also documented that they have limited access of information and materials of the crop varieties grown widely. Furthermore, the scientific information about the weather and climate forecasting are rarely available. Therefore, there is a need of balanced approach where farmer's local knowledge and practices as well as scientific knowledge and practices blend together for the best output.

Table 4: Local level initiatives adopted by farmers to minimize the impacts of changes (anthropogenic and climatic)

\begin{tabular}{lcc}
\hline $\begin{array}{l}\text { Local level initiatives adopted to minimize impacts of anthropogenic and } \\
\text { climate changes }\end{array}$ & Yes & No \\
\hline Planted different crops together & $86.8^{*}$ & 13.2 \\
Changes in cropping systems & 34.1 & 65.9 \\
Changed planting locations of crops & $67.6^{*}$ & 32.4 \\
Changed planting time & 50 & 50 \\
Kept more livestock, instead of depending on crops & $60.4^{*}$ & 39.6 \\
Planted trees & $52.2^{*}$ & 47.8 \\
Done more water harvesting & 6.6 & 93.4 \\
Done more off-farm work, instead of farming & $73.6^{*}$ & 26.4 \\
Soil management & $69.8^{*}$ & 30.2 \\
\hline
\end{tabular}

Note: * represents the percentage above 50. 


\section{CONCLUSION}

The present study focuses on the local crop diversity and its management by the farmers in Kailash Sacred Landscape area of far-western Nepal. The crop diversity in farmer's field is high with higher varietal diversity in major crops like maize, paddy, wheat, finger millet and barley. These diversity could be considered as potential units for maintaining species as well as varietal diversity and conserving the important plant genetic resources for food, nutritional as well as cultural security. However, a number of varieties as well as the species are being lost and threatened due to anthropogenic and climate drivers of change. Despite genetic erosion happening, local people are initiating a number of adaptation strategies and practices to minimize the loss. Self-conserved seed contributed as the major source of planting material followed by exchange of seeds and information with neighbors.

Awareness raising among and between the farmers are necessary. Local level crop diversity fair and other cultural fair enhance farmers' understanding about the status as well as the importance of their own varieties maintained by them. It also provides information about the seed source within the community. So, such events should be organized in the accessible areas where farmers can participate and benefit from cross-exchange.

Strengthening the local seed supply system of the local crop varieties is very important for the onfarm management of crop diversity in the village. It is also important to constantly monitor the changes of the crop varietal diversity. This is important particularly to those threatened crop species with its associated reasons. Informal as well as the formal network should be established between community people and ex-situ conservation. The species that are threatened could be placed in a national gene bank under the National Agriculture Research Council.

\section{ACKNOWLEDGEMENTS}

This study was carried out under Kailash Sacred Landscape Conservation and Development Initiative (KSLCDI) of the International Centre for Integrated Mountain Development (ICIMOD). We wish to thank all the respondents and community members of Khar VDC of Darchula district who patiently shared their time, insights and views about agricultural crop diversity and its status in the area. Authors would like to thank Mr. Bhumiraj Upadhyay, warden of Api-Nampa Conservation Area of Government of Nepal and his team for coordination and logistic support while conducting the survey. We also like to acknowledge guidance and support of Ministry of Forest and Soil Conservation, Goverrnment of Nepal for implementing KSLCDI. Authors would like to thank ICIMOD and RECAST for providing support to facilitate this research in Kailash Sacred Landscape area of Darchula Nepal. We wish to thank Ms. Sabarnee Tuladhar from ICIMOD for helping us in designing questionnaire and facilitating in data entry and analysis. Last but not least, we would like to thank Department for International Development (DFID)-UK Aid, German Federal Ministry of Economic Cooperation and Development and German International Cooperation (GIZ) for providing financial support for the KSLCDI. 


\section{REFERENCES}

Aase, T.H. Chaudhary, R.P. and Vetaas, O.R., 2009. Farming flexibility and food security under climatic incertainty: Manang, Nepal Himalaya. Area 42 (2):228-238.

Abioye, A.,Zaid, Y. and Egberongbe, H.S., 2011. Documenting and Disseminating Agricultural Indigenous Knowledge For Sustainable Food Security: The Efforts of Agricultural Research Libraries in Nigeria, 78 -Information systems for indigenous knowledge in agriculture - Agricultural Libraries Special Interest Group, World library \& Information Congress $77^{\text {th }}$ IFLA General Conference and Assembly 13-18 August, 2011, San Juan.z

Agnihotri, R. K. and Palni, L.M.S., 2007. On-farm Conservation of Landraces of Rice (Oryza Sativa L.) through Cultivation in the Kumaun Region of Indian Central Himalaya. Mountain Science. 4 (4), 354-360.

Ajani, E. N. Mgbenka, R.N. and Okeke, MN, 2013. Use of Indigenous Knowledge as a Strategy for Climate Change Adaptation among Farmers in sub-Saharan Africa: Implications for Policy, Asian Journal of Agricultural Extension, Economics \& Sociology, 2(1): 23-40Di Falco, S. and Perrings, C., 2005. Crop biodiversity, risk management and the implications of agricultural assistance. Journal of Ecological Economics 55: 459-466

Baldinelli, G.M., 2014. Agrobiodiversity conservation as a coping strategy: Adapting to climate change in the Northern highlands of Bolivia. Consilience: sustainable development. 11(1):153-166.

Baral, H., Keenan, R.J., Fox, J.C., Stork, N.E., Kasel, S., 2012. Spatial assessment of ecosystem goods and services in complex production landscapes: A case from south-eastern Australia. Ecological Complexity. 13:35-45.

Bellon, M.R. 2008. Do we need crop landraces for the future? Realizing the global option value of in situ conservation. In Agro biodiversity and Economic Development Kontoleon A, Pascual U \& Smale M (Eds.), Routledge, New York, NY, USA. Pp: 51-61.Chaudhary, P. Gauchan, D. Rana, R.B.Sthapit, B.R. andl Jarvis, DI.2004. Potential loss of rice landraces from a Terai community in Nepal: a case study from Kachorwa, Bara. Plant Genetic Resource Newsletter 137: 14-22.

Berkes, F., Colding, J., \& Folke, C. 2000.Rediscovery of traditional ecological knowledge as adaptive management.Ecological Applications, 10(5), 1251-1262.

Bisht, I.S; Mehta, P.S; Bhandari, D.C., 2007. Traditional crop diversity and its conservation on-farm for sustainable agricultural production in Kumaon Himalaya of Uttaranchal state: A case study. Genetic resources and crop evolution 54: 345-357

CBS, 2012. National population and housing census 2011. A national report published by Government of Nepal, Nepal Planning Commission Secretariat, Kathmandu, Nepal

Chaudhary, P. and Aryal, K.P, 2009. Global warming in Nepal: challenges and policy imperatives. J. Forest and Livelihood. 8:4-13. Chaudhary, P., Rai, S., Wangdi, S., Mao, A., Rehman, N., Chettri, S. and Bawa, K. S. 2011. Consistency of local perceptions of climate change in the Kangchenjunga Himalaya landscape. Current Science, Vol. (101)4: 504-513

Chaudhary, P. Rai, S. Wangdi, S. Mao, A. Rehman, N. Chettri, S. and Bawa, K. S., 2011. Consistency of local perceptions of climate change in the Kangchenjunga Himalaya landscape. Current Science, Vol. 101, No 4: $504-513$

Chaudhary, R.P. Aase, T.H. and Vetaas, O.R., 2007. Globalisation and Peoples Livelihood: Assessment and Prediction for Manang, Trans-Himalayas, Nepal. In Chaudhary et al. (Eds), local effects of global changes in the Himalayas: Manang, Nepal. Pp 1-22.

Di Falco, S. and Perrings, C., 2005.Crop biodiversity, risk management and the implications of agricultural assistance. Ecological economics 55: 459-466

Galluzzi, G. Eyzaguirre, P. and Negri, V., 2010. Home gardens: neglected hotspots of agro-biodiversity and cultural diversity. Biodivers Conserv 19: 3635-3654.

Hodgkin, T. Rana, R. Tuxill, J. Didier, B. Subedi, A. Mar, I. Karamura, R. Valdivia, R. Colledo, L. Latournerie, I. Sadiki, M. Sawadogo, M. Brown, AHD and Jarvis DI., 2006. Seed systems and crop genetic diversity in agro ecosystems. In Managing Biodiversity in agricultural ecosystems, Jarvis D, Padoch C \& Cooper D (Eds.). IPGRI \& Columbia University Press.

Hyder, S. Khatoon, S. Khan, S.H. Ali, S. Akbar, M. Ibrahim, N. and Ali, E., 2014. Inventorying of agrobiodiversity of Province Gligit-Balistan, Pakistan.Journal of Agronomy and Agricultural Research. 5(2) 134-138 
ICIMOD, 2013. Feasibility Study Report and Participatory Natural Resources Management Plan: Khar Village Development Committee in Api-Nampa Conservation Area, Darchula Nepal [Unpublished report]. International Center for Integrated Mountain Development (ICIMOD), Kathmandu, Nepal.

Katwal, T.B. Dorji, S. Dorji, R. Tshering, L. Ghimiray, M. Chhetri, G.B. Dorji, T.Y. and Tamang, A.M., 2015. Community perspectives on the on-farm diversity of six major cereals and climate change in Bhutan. Agriculture, 5: 2-16.

Negri, V., 2005. Agro biodiversity conservation in Europe: ethical issues. Journal of Agricultural Environmental Ethics18:3-25.

Oli, K.P., 2003. The potential for a transboundary protected area in the Kanchanjungha region of the Eastern Himalayas. Paper presented for the workshop on Transboundary protected areas in the governance stream of the 5th World Parks Congress, Durban, South Africa, 12-13 September.

Poudel, D. Rijal, D. Johnsen, FH. Synnevag, G. and Subedi, A., 2005. Conservation of crop genetic resources in community gene bank: farmer's willingness to pay for conservation of rice landraces in Kaski, Nepal. In On-farm conservation of Agricultural Biodiversity in Nepal, Sthapit BR, Upadhyay MP, Shrestha PK \& Jarvis DI. (Eds.) Vol (2).Managing Diversity and Promoting its Benefits, Bioversity, Rome. Pp: 149-160.

Poudel, D. Sthapit, B. and Shrestha, P., 2015. An analysis of social seed network and its contribution to on-farm conservation of crop genetic diversity in Nepal. International Journal of Biodiversity312621.

Rana, R.B, Garforth, C.J., Sthapit, B.R., Subedi, A., Chaudhary, P., Jarvis, D.I. 2007. On-farm management of rice genetic diversity: understanding farmers' knowledge on rice ecosystems and varietal deployment. Plant Genetic Resources Newsletter, 152:58-64

Regmi, B.R. Thapa, L. Suwal, R. Khadka, S. Sharma, G.B. and Tamang, B.B., 2009. Agro-biodiversity management: an opportunity for mainstreaming community-based adaptation to climate change. Journal of forest and livelihood 8(1): 111-121

Rijal, D.K. Kadayat, K.B. Baral,K.P. Pandey, Y.R. Rana, R.B. Subedi, A. Joshi,K.D. Sherchand,K.K. and Sthapit, B.R., 1998. Diversity Fairs Strengthens On-farm Conservation.APO Newsletter No. 26.

Rijal, D.K., 2007. On-farm conservation and use of local crop diversity: Adaptations of Taro (Colocasia esculenta) and Rice (Oryza sativa) diversity to varying ecosystems of Nepal. PhD thesis. University of Life Sceinces (UMB), Norway.

Salick, J. and Byg, A., 2007. Indigenous Peoples and Climate Change University of Oxford and. Missouri Botanical Garden. http://www.tyndall.ac.uk/publications/Indigenouspeoples.pdf - accessed 8 February 2017

Singh, S.P. Singh, V. and Skutsch, M., 2010. 'Rapid warming in the Himalayas: Ecosystem responses and development options.' Climate Change and Development 2:1-13

Sperling, L. and McGuire, S.J., 2010. Understanding and strengthening informal seed markets. Experimental Agriculture 46:119-136. doi:10.1017/ S0014479709991074

Sunwar, S. Thornstrom, C.G. Subedi, A. Bystrom, M., 2006. Home gardens in western Nepal: opportunities and challenges for on-farm management of agrobiodiversity. Biodiver Conserv 15:4211-4238

Upadhyay, MP.and Subedi, A., 2003. Good practices for managing in-situ conservation of agro biodiversity onfarm. In: Sthapit BR, Upadhyay MP, Subedi A \& Joshi BK (eds.), On-farm management of agricultural biodiversity in Nepal, Proceedings of National workshop, 24-26 April 2001. Lumle, Nepal. Pp: 271-276. NARC/LI-BIRD/IPGRI.

Upreti, B.R., 2000. The effects of changing land use systems in agricultural biodiversity: experiences and lessons from Nepal. In Links between the Culture and Biodiversity, Xu J. (Eds.).Yunnan Science and Technology, Yunnan, China. Pp: 327-337.

Upreti, BR. and Upreti, Y.G., 2002. Factors leading to agro-biodiversity loss in developing countries: the case of Nepal. Biodiversity Conservation11(9):1607-1621

Usher, P.J., 2000. Traditional Ecological Knowledge in Environmental Assessment and Management. 53 (2):183193

Verma, N. Rana, M. K. Negi, K. S. Kumar, G. Bhat, K. V. Park, Y. J. and Bisht, I. S., 2010. Assessment of genetic diversity in Indian Perilla [Perilla frutescens (L.)Britton] landraces using STMS markers. Indian Journal of Biotechnology. 9: 43-49

Zomer, R. and Oli, K.P. (eds.), 2011.Kailash Sacred Landscape Conservation Initiative- Feasibility assessment report. Kathmandu: ICIMOD 